\section{Synthesis of nanocomposite material through modification of graphene oxide by nanocellulose}

K. Akatan ${ }^{1,2^{*}}$, T.K. Kuanyshbekov ${ }^{1,2}$ S.K. Kabdrakhmanova ${ }^{1,3}$, A.A. Imasheva ${ }^{1,2}$ A.K. Battalova ${ }^{1,2}$, R.B. Abylkalykova ${ }^{1}$ A.K. Nasyrova ${ }^{1}$, Zh.E. Ibraeva ${ }^{4}$

${ }^{1}$ Sarsen Amanzholov East Kazakhstan University, Ust-Kamenogorsk, Kazakhstan ${ }^{2}$ Scientific Center of Composite Materials, Almaty, Kazakhstan ${ }^{3}$ Satbayev University, Almaty, Kazakhstan ${ }^{4}$ Abay Kazakh National Pedagogical University, Almaty, Kazakhstan *E-mail: ahnur.hj@mail.ru
Intensive research of nanocomposites contributes to the development of new materials in the fields of medicine, nanoelectronics, energy, biotechnology, information technology. Therefore, the synthesis of new materials by modifying of graphene oxide (GO) with nanocellulose and the study of its properties are of great interest. In this study synthesized nanocomposite materia by modifying of graphene oxide (GO) from activated carbon (BAU-A) in a 1:1 volume ratio with nanocellulose (NC) from hemp stems belonging to the annual plant, and their chemical structure was studied by FTIR and UV-spectroscopy. The results of the study showed the absorption of the etheric bond $C=O$ in the UV spectrum at full length $243 \mathrm{~nm}$. The IR spectrum showed all the new etheric bonds $\mathrm{O}=\mathrm{C}-\mathrm{OH}$ at a wavelength of $1625 \mathrm{~cm}^{-1}$. The average particle sizes of $\mathrm{GO}$ was $352 \mathrm{~nm}$ and NC was $470 \mathrm{~nm}$ in length and $80 \mathrm{~nm}$ in width. The SEM analysis indicating the NC as a contact layer between ultralow thicknesses of the GO layers. The XRD analysis indicated GO-NC composite film is a substance comprising GO and NC. According to the results, modification of graphene oxide showed that its scope can be expanded as much as possible.

Keywords: graphene; graphene oxide; activated carbon; nanocellulose; nanocomposite.
Графен оксидін наноцеллюлоза көмегімен модификациялау арқылы нанокомпозиттік материал синтездеу

Қ. Ақатан ${ }^{1,2^{*}}$, Т.Қ. Қуанышбеков 1,2 С.қ. Қабдрахманова ${ }^{1,3}$, А.А. Имашева ${ }^{1,2}$ А.К. Батталова ${ }^{1,2}$, Р.Б. Абылкалыкова ${ }^{1}$ А.К. Насырова ${ }^{1}$, Ж.Е. Ибраева

${ }^{1}$ С. Аманжолов атындағы Шығыс Қазақстан университеті, Өскемен, Қазақстан ${ }^{2}$ Композиттік материалдар ғылыми орталығы, Алматы, Қазақстан 3Satbayev University, Алматы, Қазақстан ${ }^{4}$ Абай атындағы Қазақ ұлттық педагогикалық университеті, Алматы, Қазақстан *E-mail: ahnur.hj@mail.ru
Нанокомпозиттер саласының интенсивті зерттелуі медицина, наноэлектроника, энергетика, биотехнология, информациялық технология салаларында жаңа материалдар жасалуына әсер етеді. Сондықтан графен оксидін (ГО) наноцеллюлозамен (НЦ) модификациялау арқылы жаңа материалдар синтездеу және оның қасиеттерін зерттеу барынша қызығушылық тудыруда. Бұл зерттеуде белсендірілген көмірден (БАУ-А) алынған графен оксидін біржылдық өсімдікке жататын қарасора сабағынан алынған наноцеллюлозамен 1:1 көлемдік қатынасында модификациялау арқылы нанокомпозиттік материал синтезделді. Алынған нанокомпозиттін химиялық құрылысындағы ерекшеліктері ультра күлгін (УК) және инфрақызыл (ИҚ) спектроскопия әдістерімен зерттелді. Зерттеу нәтижесі бойынша УК спектрінде 243 нм толық ұзындығында эфирлік С=O байланыстың жұтылуын көрсетті. Ал Иқ спектрінде $1625 \mathrm{~cm}^{-1}$ толқын ұзындығында O=C-OH жаңа эфирлік байланыстың бар екендігін көрсетті. ГО бөлшектерінің орташа өлшемдер 352 нм, ал НЦ ұзындығы 470 нм және ені 80 нм болды. SEM талдаулары бойынша НЦ ГО ультра қалыңдықтағы қабаттары арасындағы байланыс қабаты ретінде болатындығын көрсетті. Рентгендік талдау бойынша ГО-НЦ композициялық пленкасының құрамы жағынан ГО және НЦ тұратындығын көрсетті. Алынған нәтижелер бойынша графен оксидін модификациялау оның қолданылу аясын барынша кеңейтуге болатындығын көрсетті.

Түйін сөздер: графен; графен оксиді; белсендірілген көмір; наноцеллюлоза; нанокомпозит.

\section{Синтез нанокомпозитного материала путем модификации оксида графена наноцеллюлозой}

К. Акатан ${ }^{1,2^{*}}$, Т.К. Куанышбеков ${ }^{1,2}$ С.К. Кабдрахманова ${ }^{1,3}$, А.А. Имашева ${ }^{1,2}$ А.К. Батталова ${ }^{1,2}$, Р.Б. Абылкалыкова ${ }^{1}$ А.К. Насырова ${ }^{1}$, Ж.Е. Ибраева

${ }^{1}$ Восточно-Казахстанский университет имени С. Аманжолова, Усть-Каменогорск, Казахстан ${ }^{2}$ Научный центр композитных материалов, Алматы, Казахстан ${ }^{3}$ Satbayev University, Алматы, Казахстан ${ }^{4}$ Казахский национальный педагогический университет имени Абая, Алматы, Казахстан *E-mail: ahnur.hj@mail.ru
Интенсивные исследования в области нанокомпозитов способствуют разработке новых материалов в области медицины, наноэлектроники, энергетики, биотехнологий, информационных технологий. Поэтому синтез новых материалов путем модификации оксида графена (GO) наноцеллюлозой и изучение его свойств представляет большой интерес. В этом исследовании был синтезирован нанокомпозитный материал путем модификации оксида графена (GO) из активированного угля (БАУ-А) в объемном соотношении 1:1 с наноцеллюлозой (NC) из стеблей конопли, принадлежащих однолетнему растению. Их химическая структура была изучена с помощью FTIR и УФ-спектроскопия. Результаты исследования показали поглощение эфирной связи С=О в УФ-спектре при полной длине 243 нм, а в ИК-спектре обнаружены новые эфирные связи О=C-OH на длине волны $1625 \mathrm{~cm}^{-1}$. Средний размер частиц GO составлял 352 нм, а NC - 470 нм в длину и 80 нм в ширину. Анализ SEM показывает NC как контактный слой между сверхмалыми толщинами слоев GO Рентгеноструктурный анализ показал, что композитная пленка GO-NC представляет собой вещество, содержащее GO и NC. По результатам модификация оксида графена показала, что область его применения может быть максимально расширена.

Ключевые слова: графен; оксид графена; активированный уголь; наноцеллюлоза; нанокомпозит. 


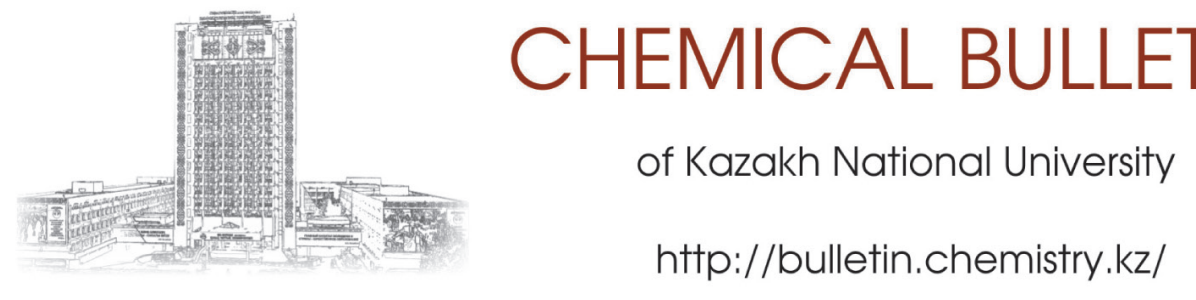

\title{
Synthesis of nanocomposite material through modification of graphene oxide by nanocellulose
}

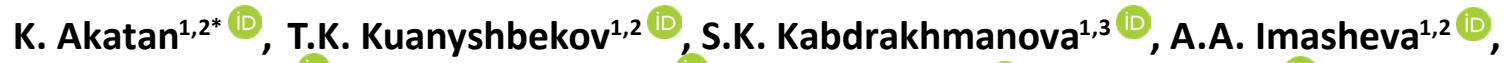 \\ A.K. Battalova ${ }^{1,2}{ }^{(\mathbb{D}}$, R.B. Abylkalykova ${ }^{1}{ }^{(\mathbb{D}}$, A.K. Nasyrova ${ }^{1}(\mathbb{D})$, Zh.E. Ibraeva ${ }^{4}$ \\ ${ }^{1}$ Sarsen Amanzholov East Kazakhstan University, 18/1 Bitibaeva str., 070002 Ust-Kamenogorsk, Kazakhstan \\ ${ }^{2}$ Scientific Center of Composite Materials, 79 Nurmakov str., 050026 Almaty, Kazakhstan \\ ${ }^{3}$ Satbayev University, 22a Satbayev str., 050013 Almaty, Kazakhstan \\ ${ }^{4}$ Abay Kazakh National Pedagogical University, 13 Dostyk ave., 050010 Almaty, Kazakhstan \\ *E-mail: ahnur.hj@mail.ru
}

\section{Introduction}

Recently, graphene, graphene oxide (GO) and carbon materials have attracted the attention of scientists, due to their unique physical-mechanical, electronic characteristics, high thermal conductivity, hardness and strength and excellent adsorption properties [1]. One of the main reasons is that the membrane made of graphene oxide is widely used in the production of sensors, sensors, supercapacitors sensitive to moisture, temperature, organic gases [2].

Currently, graphite is used as a raw material in the synthesis of GO. However, as a result of comparative studies, the value of the fixed layer diameter of $78-92 \%$ of activated carbon is on average $L_{a}=0.75 \mathrm{~nm}$, and the number of carbon atoms in each layer is $15-18$. When the carbon content exceeds $92 \%$, the diameter of the stable layer immediately increases by $1 \mathrm{~nm}$, and the number of carbon atoms in each layer becomes more than 30. Also, the structure of activated carbon differs from graphite in that it is not crystalline, but mesomorphic, it is a flat hexagonal lattice of carbon atoms with open carbon chains connected peripherally to conduct functional groups. This allows the scattered carbon atoms to combine during strong oxidation to form closed-chain, crystalline layers [3]. Activated carbon is also the most suitable source of raw material for the synthesis of graphene oxide due to its low cost compared to graphite, high adsorption capacity and high surface area.

Despite the universal nature of $\mathrm{GO}$, the main disadvantage is that the structure is unstable in a humid environment $[4,5]$. To eliminate this shortcoming, at present, the modification of graphene oxide with various substances is widespread.

The production of graphene with bio-tribological properties necessary for the biomedical industry was studied by chemical modification of GO using hydrazine hydrate [6], dimethylhydrazine [7], hydroquinone [8], $\mathrm{NaBH}_{4}$ [9].

Recently, the production of new nanocomposites by modification of $\mathrm{GO}$ with nanocellulose has become an important area of research of nanomaterials. [10-12] studies have shown that the dielectric constant of the nanocomposite obtained by ultraviolet reduction of cellulose nanoparticles films and GO in a nitrogen medium has increased to 88.9. It is known that the adsorption capacity of nanocellulose and graphene oxide membrane for RhB textile dye is $86.4 \mathrm{mg} / \mathrm{g}$ [13].

In the study, the chemical structure of the nanocomposite synthesized by mixing GO from BAU-A activated carbon and NC from hemp stalks in a ratio of 1 : 1 (volume) was studied by FTIR and ultraviolet spectroscopy.

\section{Experiment}

\subsection{Materials}

The study included activated carbon of BAU-A brand (GOST ST 6217-74), sulfuric acid ( $\left.\mathrm{H}_{2} \mathrm{SO}_{4}\right)$ 94\% (GOST ST 4204-77), sodium nitrate $\left(\mathrm{NaNO}_{3}\right)$ (GOST ST 4168-79), potassium permanganate $\left(\mathrm{KMnO}_{4}\right)$ (GOST ST 5777-84), hydrogen peroxide $\left(\mathrm{H}_{2} \mathrm{O}_{2}\right.$ ) (GOST ST 50632-93), hydrochloric acid ( $\mathrm{HCl}$ ) (GOST ST 3118-77) and all reagents were used without additional purification.

\subsection{Methods}

2.2.1 Synthesis of GO from activated carbon

$\mathrm{GO}$ is synthesized from activated carbon by the Hammers method. Preparation of GO consists of the following sequence: the flask is filled with $6 \mathrm{~g}$ of activated carbon, which is placed in an ice bath with a temperature of $0^{\circ} \mathrm{C}$ and stirred continuously 
for $15 \mathrm{~min}$, dripping $23 \mathrm{ml}$ of $94 \% \mathrm{H}_{2} \mathrm{SO}_{4}$. To the resulting suspension is added $3 \mathrm{~g}$ of $\mathrm{NaNO}_{3}$, then during the stirring the mixture gradually is added $18 \mathrm{~g}$ of $\mathrm{KMnO}_{4}$ with maintaining the temperature below $20^{\circ} \mathrm{C}$ for $2 \mathrm{~h}$, after then temperature is raised to $35^{\circ} \mathrm{C}$ and keep for $30 \mathrm{~min}$. Then after adding the deionized water, the temperature of the mixture rose to $90^{\circ} \mathrm{C}$. Finally, $30 \% \mathrm{H}_{2} \mathrm{O}_{2}$ is added until the mixture changes color to light yellow. At the end of the reaction, the product is filtered and washed several times in $5 \% \mathrm{HCl}$ solution to remove residual metal ions. Finally, neutralized with deionized water until $\mathrm{pH}=6-7$.

\subsubsection{Extraction of cellulose from hemp stalks}

The cellulose used for modification was isolated from hemp stalks (Cannabis Ruderalis Janisch) on the basis of organosolvent oxidation [14].

\subsubsection{Synthesis of nanocellulose}

To obtain NC, the $1 \mathrm{~g}$ of the original cellulose was weighed, cellulose with $64 \% \mathrm{H}_{2} \mathrm{SO}_{4}$ acid was obtained as a ratio of $1: 10(\mathrm{~g} / \mathrm{mL})$ and was titrated gradually at $0-5^{\circ} \mathrm{C}$. After complete mixing of the cellulose and acid, heat the mixture at $40^{\circ} \mathrm{C}$ in a water bath, stirring vigorously for $1 \mathrm{~h}$. The resulting suspension is separated in a centrifuge (OPn-8, Russia) with a speed of 6000 $\mathrm{rpm}$, stirring for $15 \mathrm{~min}$. The obtained nanocellulose is dialyzed in deionized water until the $\mathrm{pH}$ is 5-7.

\subsubsection{The particle size of NC and GO suspensions}

The average particle size was determined by Zetasizer NanoZS 90 (Malvern, UK) Dynamic laser light scattering. To do this, aqueous suspension was processed at $30 \mathrm{kHz}$ for $10 \mathrm{~min}$ using an ultrasonic dispersant U-sonic UZTA-0.15/22-0 (Alena, Russian).

\subsubsection{Modification of GO with NC}

To synthesize of GO modified with NC (GO-NC), the two are combined in an equimolar ratio of $50: 50 \mathrm{~mL}: \mathrm{mL}$ and processed by ultrasound at a frequency of $45 \mathrm{kHz}$ (UZTA-0.15 / 22-0, Russia) at a temperature of $25^{\circ} \mathrm{C}$ for $30 \mathrm{~min}$ (Figure 1). The fully mixed mixture was poured into a flat plastic surface and dried at room temperature for $48 \mathrm{~h}$. As a result, a film with a thickness of $38 \mu \mathrm{m}$ was formed. The samples were stored in the crystallizer to prevent sorption of water vapor and carbon dioxide in the air.

\subsubsection{UV spectroscopy}

The absorption characteristics of the obtained GO, NC and $\mathrm{GO} / \mathrm{NC}$ nanocomposite in the UV region were recorded on a spectrometer PE5400-UF at a temperature of $25^{\circ} \mathrm{C}$ in the range of 190-1100 nm (cuvette thickness $10 \mathrm{~mm}$ ) every $5 \mathrm{~nm}$.

\subsubsection{FTIR spectroscopy}

FTIR analysis was performed on a spectrometer FTIR FT801 (Simex, Russian), with a resolution of $1 \mathrm{~cm}^{-1}$ and a wavelength $450-4700 \mathrm{~cm}^{-1}$ according to the standard method using a single-use universal full internal reflection and mirrordiffuse reflection with the upper position of the model, at a temperature of $25^{\circ} \mathrm{C}$ and the number of scans 100 .

\subsubsection{SEM}

The morphology of GO/NC nanocomposite was examined under a scanning electron microscope. The surface morphology of GO/NC nanocomposite was examined by SEM Quanta 200i 3D (FEITM Netherlands). Measurements were carried out in high vacuum mode using a secondary electron detector at an accelerating voltage of $15 \mathrm{kV}$. The surface of GO/NC nanocomposite is coated with aluminum to improve the transfer of electrons. The specimens were mounted on aluminum pins with carbon tape.

\subsubsection{XRD}

The crystal structures of GO/NC nanocomposite was studied by X-ray diffraction on X'PertPRO diffractometer (Malvern Panalytical Empyrean, Netherlands) using monochromatized copper (CuK $\alpha$ ) radiation with a scan step of $0.02^{\circ}, \mathrm{K}$-Alpha1 $[\AA \AA] \mathrm{C} 0.1542$. The measurement angle was $10-45^{\circ}$, the X-ray tube voltage was $45 \mathrm{kV}$, the current intensity was $30 \mathrm{~mA}$, and the measurement time at each step was $0.5 \mathrm{~s}$ and an aluminium rectangular multi-purpose sample holder (PW1172/01) was used for the measurmentin reflection mode.

\section{Results and Discussion}

3.1 The particle size of NC and GO suspensions

In Figure 2, it can be seen that the average particle size of the GO was $352 \mathrm{~nm}$ (Figure 2a), average particle size of NC was $470 \mathrm{~nm}$ in length and $80 \mathrm{~nm}$ in width (Figure $2 \mathrm{~b}$ ).

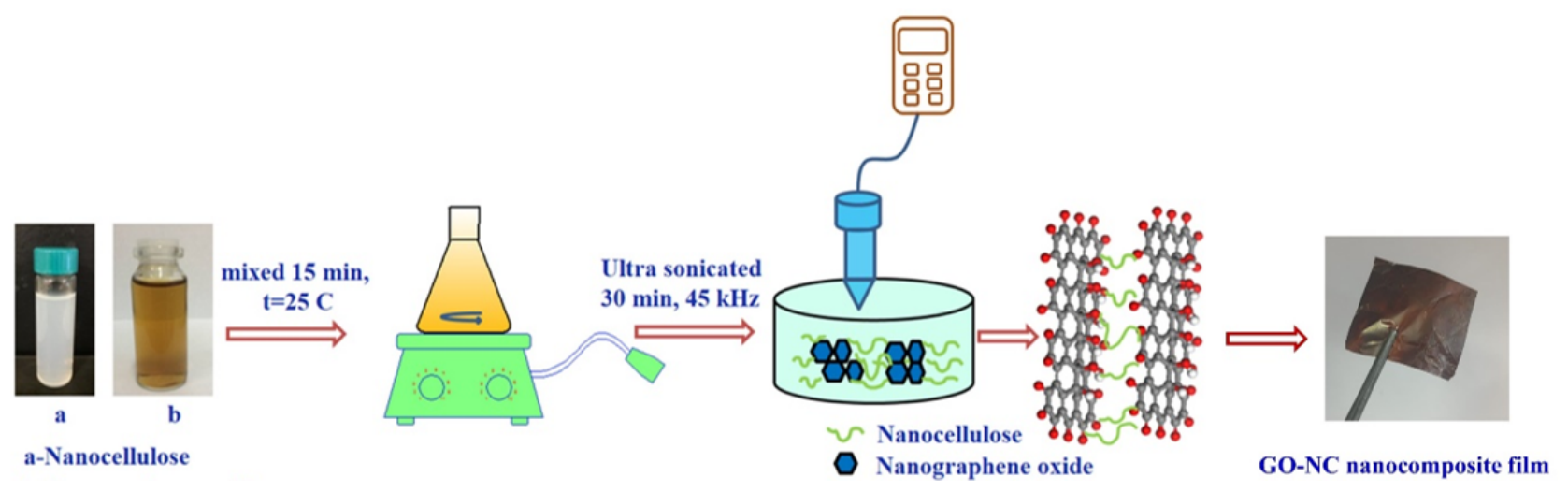

Figure 1 - Scheme of obtaining GO-NC nanocomposite film 

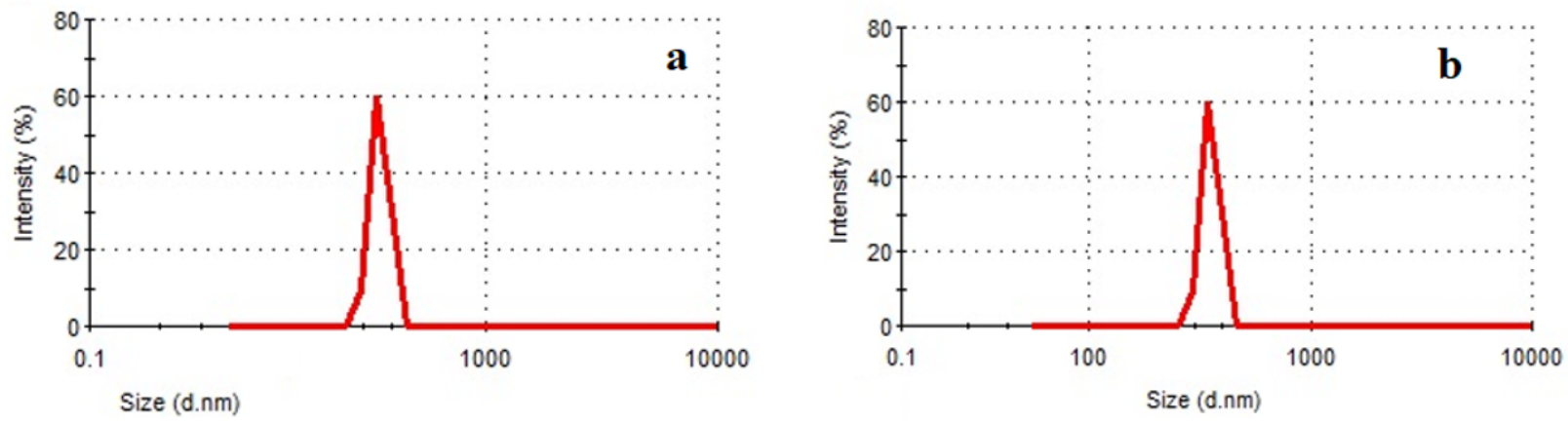

Figure $\mathbf{2}$ - The particle size of GO (a) and NC (b) suspensions

\subsection{UV spectroscopy}

Figures 3a-3b show the absorption spectra of GO and NC in the ultraviolet region. In Figure $2 a$, under the influence of $\pi-\pi$ * bonding of aromatic rings in the chemical structure of GO, UV has an absorption of $204 \mathrm{~nm}$ in the region. This was found to be well consistent with the research results [15-16]. The absorption spectrum in the UV region of $231 \mathrm{~nm}$, shown in Figure $2 \mathrm{~b}$, confirms the synthesis of cellulose nanoparticles. The study [1718] corresponds to the indicators given in the works. Absorption of GO-NC nanocomposite in the UV region was observed at a wavelength of $243 \mathrm{~nm}$ (Figure 2c). This indicates that the ether $\mathrm{C}=\mathrm{O}$ carboxyl bond is associated with valence stretching [19-20].

\subsection{FTIR spectroscopy}

Figure 4a shows FTIR of the initial GO. The FTIR spectrum of GO in Figure 4, shows a broad peak appeared at $3226 \mathrm{~cm}^{-1}$ and at $1420 \mathrm{~cm}^{-1}$ attributed to the stretching vibration mode of $\mathrm{O}-\mathrm{H}$ bond. The band observed at $1723 \mathrm{~cm}^{-1}$ was assigned to the stretching vibration of $\mathrm{C}=\mathrm{O}$ bonds in the carbonyl and carboxyl groups. The band at $1585 \mathrm{~cm}^{-1}$ corresponds to the stretching vibration and deformation peaks of the aromatic ring $\mathrm{C}=\mathrm{C}$ bonds. The epoxy functional groups are shown at $1249 \mathrm{~cm}^{-1}$ as $\mathrm{C}-\mathrm{O}$ stretching vibration and at peak $1054 \mathrm{~cm}^{-1}$ is attributed as stretching vibration of $\mathrm{C}-\mathrm{O}$ alkoxy bonds [21-23].

Figure 4a shows the IR spectrum of nanocellulose. The absorbance region in the wavenumber $900 \mathrm{~cm}^{-1}$ is assigned to
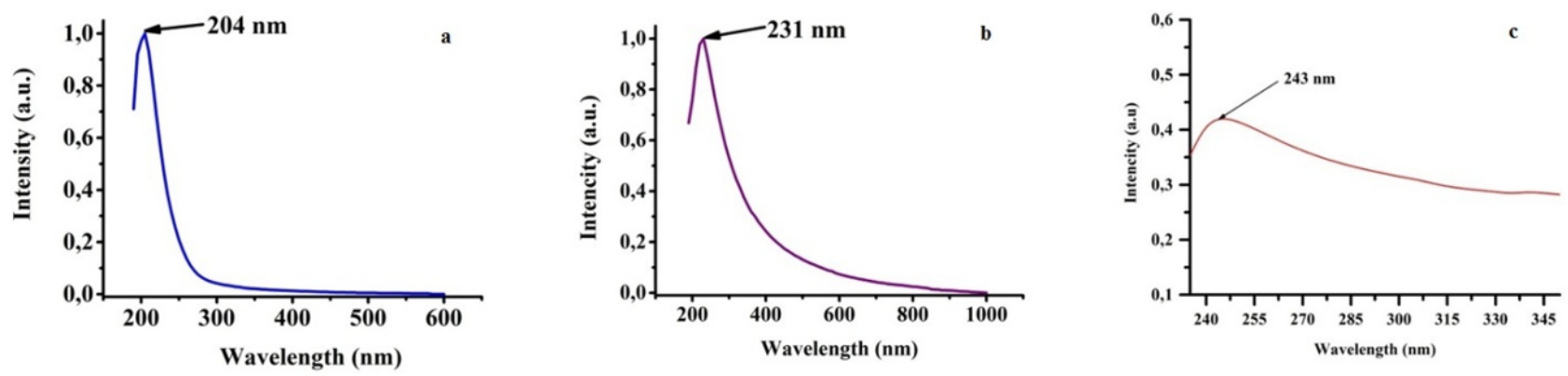

Figure 3 - Absorption spectra of GO (a), NC (b) and GO-NC (c) nanocomposites in the ultraviolet region
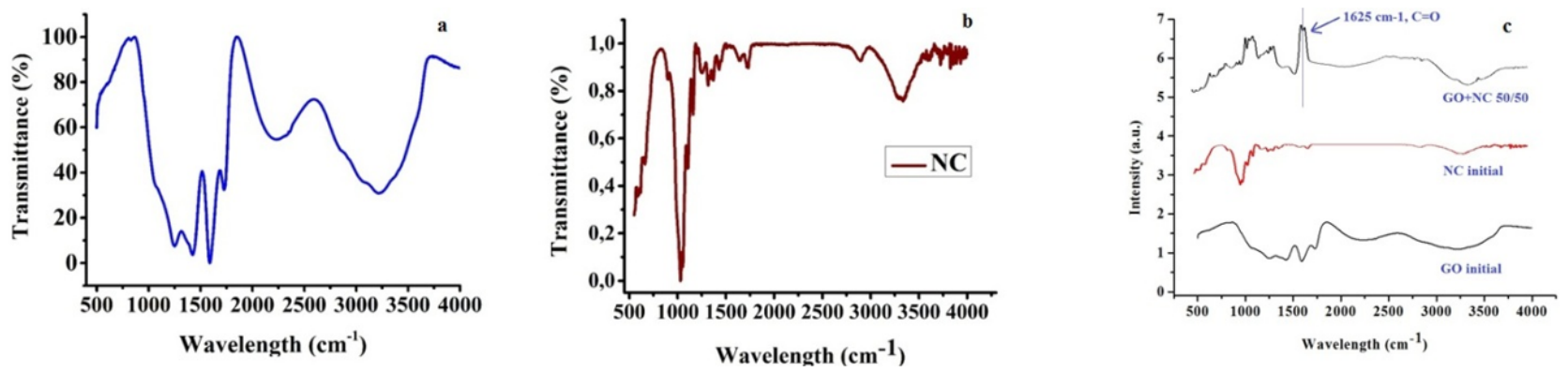

Figure 4 - FTIR spectra of GO (a), NC (b) and GO-NC (c) nanocomposites 
the deformation of glycoside $\mathrm{C}-\mathrm{H}$ bond. The absorption peaks in the cellulose molecule, which are observed at $1100 \mathrm{~cm}^{-1}$, $1430 \mathrm{~cm}^{-1}, 2880 \mathrm{~cm}^{-1}$, consequently, they are associated with the symmetrical and asymmetric signals stretching vibration of the $\mathrm{C}-\mathrm{O}, \mathrm{CH}_{2}, \mathrm{C}-\mathrm{H}$ groups. The broad absorbance band appearing in the range from $3300 \mathrm{~cm}^{-1}$ to $3500 \mathrm{~cm}^{-1}$ is characterized to the valence stretching vibration of the $\mathrm{O}-\mathrm{H}$ groups. It can be seen that the results of the study are in good agreement with the work $[24,25]$.

Figure 4c shows the IR spectra of the GO-NC nanocomposite. One of the significant changes in the IR spectrum is the occurrence of valence stretching vibration of the ether carboxyl
$\mathrm{C}=\mathrm{O}$ bond in the absorption region of $1625 \mathrm{~cm}^{-1}$. That is, an etheric $\mathrm{O}=\mathrm{C}-\mathrm{OH}$ bond is formed between the $\mathrm{OH}$ group in the cellulose molecule and the carboxyl groups in the GO molecule. This is consistent with the results of the study [19-21].

\subsection{SEM analysis}

Figure 5 shows surface morphology of the GO-NC nanocomposite film. The SEM images indicating the CNF as a contact layer between ultralow thickness of the $\mathrm{GO}$ layers. Some of the GO sheets were inserted perpendicular (standing) to the membrane surface, while most of the GO assem horizontally on top of the CNF. It can be seen that the results of the study are well consistent with the literature [26].
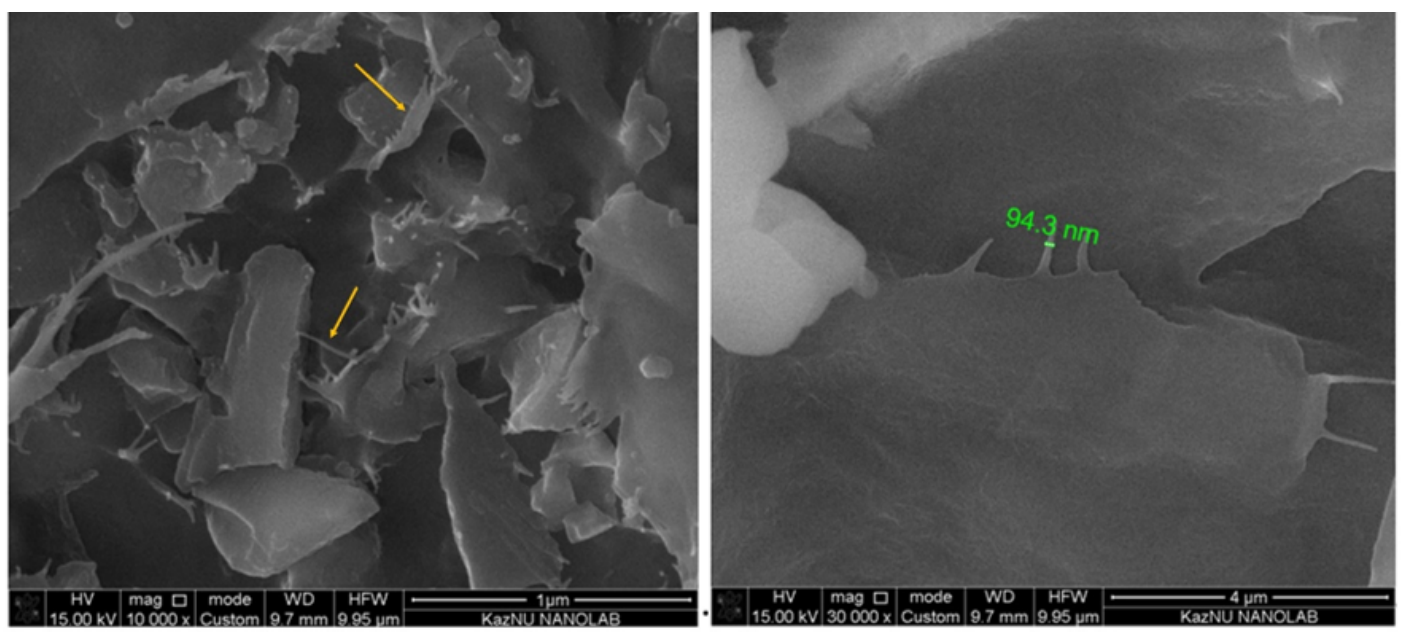

Figure 5 - SEM images of GO-NC nanocomposite film

\subsection{XRD analysis}

Figure 6 shows the changes of crystal structures of GO, NC and GO-NC composite films were also characterized by XRD. Figure $4 \mathrm{a}$ four diffraction peaks detected from all X-ray

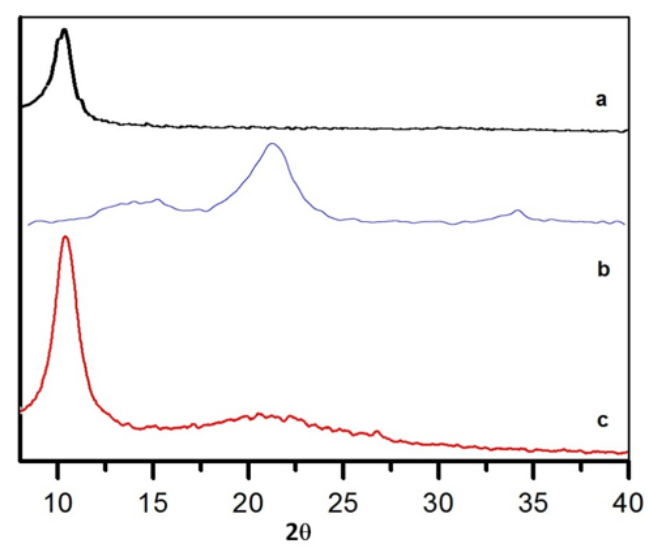

Figure 6 - XRD patterns of the GO (a), NC (b) and GO-NC composite film (c) diffractograms. The $2 \theta=10.5^{\circ}$ corresponds to the characteristic peak of GO (001) lattice plane (Figure 4a) [27]. In the figure $4 b$, they are equal to $2 \theta=15.8$ (1-10), 16.2 (110), 22.5 (200), 34.2 (004), and the crystal structure of the molecule is characteristic of two chains monoclinic unit per unit cell cellulose I $\beta$ [28]. Additionally, in the figure $4 \mathrm{c}$ GO-NC composite film exhibited the (200) crystal plane of NC at $2 \theta=22.5^{\circ}$, Further, the peak occurring at $2 \theta=10.21^{\circ}(001)$ indicates that the composite film also retains the characteristics of $\mathrm{GO}$. It can be proven that the GO-NC composite film is a substance comprising GO and NC.

\section{Conclusion}

Based on the obtained results, for the first time GO was synthesized from activated carbon-BAU-A and modified with NC to obtain the nanocomposite GO-NC. The obtained GO and NC average particle sizes of the GO and NC were $352 \mathrm{~nm}, 470$ $\mathrm{nm}$ in length and $80 \mathrm{~nm}$ in width. According to the FTIR spectrum, an etheric $\mathrm{O}=\mathrm{C}-\mathrm{OH}$ bond between the $\mathrm{OH}$ group in the NC molecule and the carboxyl groups in the $\mathrm{GO}$ molecule formed. The absorption signal at $243 \mathrm{~nm}$ in the ultraviolet region observed in the GO-NC nanocomposite showed that the 
IR spectrum is associated with $\mathrm{C}=\mathrm{O}$ stretching vibration of carboxyl groups characterized by a wavelength of $1625 \mathrm{~cm}^{-1}$. The SEM analysis showed the NC as a contact layer between ultralow thickness of the $\mathrm{GO}$ layers. The XRD analysis indicated GO-NC composite film is a substance comprising GO and NC.

\section{Conflict of interests}

On behalf of all authors, the corresponding author states that there is no conflict of interest.

\section{Acknowledgment}

This study was supported by the Ministry of Education and Science of the Republic of Kazakhstan within the framework of Grant No. AP09058548 « Development of a sensitive humidity sensor based on a graphene oxide membrane obtained from activated carbon for military needs » (2021-2023).

\section{References (GOST)}

1 Wang R., Ma Q., Zhang H., Ma Z., et al. Producing conductive graphene-nanocellulose paper in one-pot // Journal of Polymers and the Environment volume. - 2019. - Vol.27. - P.148-157.

2 Nayak J., Vashishtha A. Synthesis, characterization and preparation of nanocellulose and different cellulose/nanocellulose/ graphene composites from Cassava root and its potential application for pesticide adsorption from water // IJRAR. - 2018. - Vol.5, Is.4. - P.513-524.

3 Savitskyi D.P., Makarov A.S., Goncharuk V.V. Preparation of a colloidal graphene oxide solution from natural coal // Reports of the National Academy of Sciences of Ukraine. - 2016. - Is.6. - P.87-94. (In Russian)

4 Huang H., Ying Y., Peng X. Graphene oxide nanosheet: an emerging star material for novel separation membranes // Journal of Materials Chemistry A. - 2014. - Vol.2. - P.13772-13782.

5 Yeh C., Raidongia K., Shao J., Yang Q., Huang J. On the origin of the stability of graphene oxide membranes in water // Nature Chemistry. - 2015. - Vol.7. - P.166-170.

6 Stankovich S., Dikin D.A., Piner R.D., Kohlhaas K.A., et al. Synthesis of graphene-based nanosheets via chemical reduction of exfoliated graphite oxide // Carbon. - 2007. - Vol.45. - P.1558-1565.

7 Stankovich S., Dikin D.A., Dommett G.H.B., Kohlhaas K., et al. Graphene-based composite materials // Nature. - 2006. Vol.442. - P.282-286.

8 Wang L., Ye Y., Lu X., Wu Y., et al. Prussian blue nanocubes on nitrobenzene-functionalized reduced graphene oxide and its application for H2O2 biosensing // Electrochimica Acta. - 2013. - Vol.114. - P.223-232.

$9 \quad$ Si Y., Samulski E.T. Synthesis of water soluble graphene // Nano Letterss. - 2008. - Vol.8. - P.1679-1682.

10 Weng Z., Su Y., Wang D.W., Li F., et al. Graphene-cellulose paper flexible supercapacitors // Advanced Energy Materials. 2011. - Vol.1, Is.5. - P.917-922.

11 Du X., Zhang Z., Liu W., Deng Y. Nanocellulose-based conductive materials and their emerging applications in energy devices A review // Nano Energy. - 2017. - Vol.35. - P.299-320.

12 Wang N., Wang Y.F., Omer A.M., Ouyang X. Fabrication of novel surface-imprinted magnetic graphene oxide-grafted cellulose nanocrystals for selective extraction and fast adsorption of fluoroquinolones from water // Analytical and Bioanalytical Chemistry. - 2017. - Vol.409. - P.6643-6653.

13 Tian S.Y., Guo J.H., Zhao Ch., et al. Preparation of cellulose/graphene oxide composite membranes and their application in removing organic contaminants in wastewater // Journal of Nanoscience and Nanotechnology. - 2019. - Vol.19. - P.2147-2153.

14 Imasheva A.A., Kabdraxmanova S.K., Ibraeva J.E., et al. Conditions for producing cellulose from wastes of oily cultures, research of morphology and properties // NNC RK Bulletin. - 2020. - Is.1. - P.35-38. (In Kazakh)

15 Marcano D.C. Improved synthesis of graphene oxide // ACS Nano. - 2010. - Vol.4. - P.4806-4814.

16 Peng L., Xu Zh., Liu Zh., et al. An iron-based green approach to 1-h production of single-layer graphene oxide // Nature Communications. - 2015. - Vol.6. - ID5716.

17 Plermjai K., Boonyarattanakalin K., Mekprasart W., Pavasupree S., et al. Extraction and characterization of nanocellulose from sugarcane bagasse by ball-milling-assisted acid hydrolysis // AIP Conference Proceedings. 2010. - ID020005.

18 Sirvio J.A., Visanko M., Heiskanen J.P., Liimatainen H. UV-absorbing cellulose nanocrystals as functional reinforcing fillers in polymer nanocomposite films // Journal of Materials Chemistry A. - 2016. - Vol.4. - P.6368-6375.

19 Szabo T., Berkesi O., Dekany I. Free-green synthesis and dynamics of reduced graphene sheets via sun light irradiation // Carbon. - 2005. - Vol.43. - P.3186-3189.

20 Shen L., Shen H.S., Zhang C.L. Temperature-dependent elastic properties of single layer graphene sheets // Materials \& Design. - 2010. - Vol.31. - P.4445-4449.

21 Wojtoniszaka M.X., Chena R.J., Wajdab K.A., et al. Synthesis, dispersion, and cytocompatibility of graphene oxide and reduced 
graphene oxide // Colloids and Surfaces B: Biointerfaces. - 2012. - Vol.89. - P.79-85.

22 Qi C., Yang L., Xu H., He S., Men Y. Natural polysaccharides-modified graphene oxide for adsorption of organic dyes from aqueous solutions // Journal of Colloid and Interface Science. - 2017. - Vol.486. - P.84-96.

23 Tang G., Jiang Z.G., Li X., et al. Three dimensional graphene aerogels and their electrically conductive composites // Carbon. 2014. - Vol.77. -P.592-599.

24 Kian L.K., Jawaid M., Ariffin H., Alothman O.Y. Isolation and characterization of microcrystalline cellulose from roselle fibers // International Journal of Biological Macromolecules. - 2017. - Vol.103. - P.931-940.

25 Haafiz M.K.M., Hassan A., Zakaria Z., Inuwa I.M. Isolation and characterization of cellulose nanowhiskers from oil palm biomass microcrystalline cellulose // Carbohydrate Polymers. - 204. - Vol.103. - P.119-125.

26 Liu P., Zhu C., Mathe A. Mechanically robust high flux graphene oxide - nanocellulose membranes for dye removal from water // Journal of Hazardous Materials. - Vol.371. - P.484-493.

27 Compton O.C., Jain B., Dikin D.A., et al. chemically active reduced graphene oxide with tunable C/O ratios. - 2011. - Vol.5. P.4380-4391.

28 French A.D. Idealized powder diffraction patterns for cellulose polymorphs // Cellulose. - 2014. - Vol.21. - P.885-896.

\section{References}

1 Wang R, Ma Q, Zhang H, Ma Z et al (2019) J Polym Environ 27:148-157. https://doi.org/10.1007/s10924-018-1330-4

2 Nayak J, Vashishtha A (2018) IJRAR 5(4):513-524. https://doi.org/10.1729/Journal.18989

3 Savitskyi DP, Makarov AS, Goncharuk VV (2016) Reports of the National Academy of Sciences of Ukraine 6:87-94. (In Russian). https://doi.org/10.15407/dopovidi2016.06.087

$4 \quad$ Huang $H$, Ying Y, Peng X (2014) J Mater Chem A 2:13772-13782. https://doi.org/10.1039/C4TA02359E

5 Yeh C, Raidongia K, Shao J, Yang Q, Huang J (2015) Nat Chem 7:166-170. https://doi.org/10.1038/nchem.2145

6 Stankovich S, Dikin DA, Piner RD, Kohlhaas KA, et al (2007) Carbon 45:1558-1565. https://doi.org/10.1016/j.carbon.2007.02.034

7 Stankovich S, Dikin DA, Dommett GHB, Kohlhaas K, et al (2006) Nature 442:282-286. https://doi.org/10.1038/nature04969

8 Wang L, Ye Y, Lu X, Wu Y, et al (2013) Electrochim Acta 114:223-232. https://doi.org/10.1016/j.electacta.2013.10.073

9 Si Y, Samulski ET (2008) Nano Lett 8:1679-1682. https://doi.org/10.1021/nl080604h

10 Weng Z, Su Y, Wang DW, Li F, et al (2011) Adv Energy Mater 1(5):917-922. https://doi.org/10.1002/aenm.201100312

11 Du X, Zhang Z, Liu W, Deng Y (2017) 35:299-320. https://doi.org/10.1016/j.nanoen.2017.04.001

12 Wang N, Wang YF, Omer AM, Ouyang X (2017) Anal Bioanal Chem 409:6643-6653. https://doi.org/10.1007/s00216-017-0619-9

13 Tian SY, Guo JH, Zhao Ch, et al (2019) J Nanosci Nanotechno 19:2147-2153. https://doi.org/10.1166/jnn.2019.15808

14 Akatan K, Kabdraxmanova SK, Imasheva AA, Abilev MB, Ibraeva JE, Kudaibergenov SE (2020) NNC RK Bulletin 1(81):35-38. (In Kazakh)

15 Marcano DC (2010) ACS Nano 4:4806-4814. https://doi.org/10.1021/nn1006368

16 Peng L (2015) Nature Comm 6(1):5716. https://doi.org/10.1038/ncomms6716

17 Plermjai K, Boonyarattanakalin K, Mekprasart W, Pavasupree S, et al (2010) AIP Conference Proceedings 020005. https://doi. org/10.1063/1.5053181

18 Sirvio JA, Visanko M, Heiskanen JP, Liimatainen H (2016) J Mater Chem A 4:6368-6375. https://doi.org/10.1039/C6TA00900J

19 Szabo T, Berkesi O, Dekany I (2005) Carbon 43:3186-3189. https://doi.org/10.4236/graphene.2015.43006

20 Shen L, Shen HS, Zhang CL (2010) Mater Design 31:4445-4449. https://doi.org/10.1016/j.matdes.2010.04.016

21 Wojtoniszaka MX, Chena RJ, Wajdab KA, et al (2012) Colloid Surface B 89:79-85. https://doi.org/10.1016/j.colsurfb.2011.08.026

22 Qi C, Yang L, Xu H, He S, Men Y (2017) J Colloid Interf Sci 486:84-96. https://doi.org/10.1016/j.jcis.2016.09.058

23 Tang G, Jiang ZG, Li X et al (2014) Carbon 77:592-599. https://doi.org/10.1016/j.carbon.2014.05.063

24 Kian LK, Jawaid M, Ariffin H, Alothman OY (2017) Int J Biol Macromol 103:931-940. https://doi.org/10.1016/j.ijbiomac.2017.05.135

25 Haafiz MKM, Hassan A, Zakaria Z, Inuwa IM (2014) Carbohyd Polym 103:119-125. https://doi.org/10.1016/j.carbpol.2013.11.055

26 Liu P, Zhu C, Mathe A (2019) J Hazard Mater 371:484-493. https://doi.org/10.1016/j.jhazmat.2019.03.009

27 Compton OC, Jain B, Dikin DA, et al (2011) ACS Nano 5:4380-4391. https://doi.org/10.1021/nn1030725

28 French AD (2014) Cellulose 21:885-896. https://doi.org/10.1007/s10570-013-0030-4 